31. Archiwum Główne Akt Dawnych w Warszawie (AGAD) [Central Archives of Historical Records in Warsaw (AGAD)]. Zespol 191. KRSW. Sygnatura 7695. Kurs a falszowanie monet. Vol. VI. (1835-1837). Str. 283-284 odw. [in Polish].

32. Archiwum Państwowe $w$ Warszawie (APW) [The State Archives in Warsaw (APW)]. Zespol 1416/II. KGW. Referat I Tajny. Sygnatura. 3. Секретное дело о распространении польским выходцем Адамом Богушем фальшивых кредитных русских билетов. Rok 18681871. Str. 1-2[in Polish].

33. Kotsur, V. \& Boiko-Gagarin, A. (2019) Napoleon russian forged assignations in Naddniprianshchyna (over Dnipro land). East European historical bulletin. (11). Drohobych. pp. 66-77 [in English].

Одержано 20.05.2019.

УДК 930.2(092)(477.5) «1816/2019»

\author{
Вуйко Богдан, \\ аспірант кафедри історії та культури \\ України \\ mega-bogdan59@ukr.net \\ http://orcid.org/0000-0002-9296-6042 \\ Державний вищий навчальний заклад \\ «Переяслав-Хмельницький державний \\ педагогічний університет імені Григорія \\ Сковороди», \\ вул. Сухомлинського, 30, \\ м. Переяслав-Хмельницький, Київська обл., \\ Україна, 08401
}

\section{DOI https://doi.org/10.31470/2415-3567- 2019-46-218-225}

\section{Vuiko Bogdan,}

a post graduate student of Department of

History and Culture of Ukraine

mega-bogdan59@ukr.net

http://orcid.org/0000-0002-9296-6042

Pereiaslav-Khmelnytsky Hryhorii Skovoroda

State Pedagogical University,

30, Sukhomlynsky Str.,

Pereiaslav-Khmelnytskyi, Kyiv region,

Ukraine, 08401

\title{
ІСТОРІОГРАФІЧНІ РЕФЛЕКСІЇ ЩОДО УЧАСТІ М.Г. РЕПНІНА (ВОЛКОНСЬКОГО) В НАПИСАННІ «ИСТОРИИ МАЛОЙ РОСИИ» Д.М. БАНТИШ-КАМЕНСЬКИМ
}

У статті здійснено аналіз історіографії щзодо вагомої ролі М.Г. Рєпніна (Волконського) у підготовиі, написанні та оприлюднені першої синтетичної праці «Истории Малой Росии» Д.М. Бантиш-Каменським. Встановлено, щэо дослідники в ХІХна початку XXI cm. розглядали внесок М.Г. Рєпніна в справу підготовки та написання історії України з різних наукових позицій. Д.І. Дорошенко вважав, щзо написання історії Украйни є справою політичною. Показано, щчо на сучасному етапі украйнські науковці віддаючи належне постаті М.Г. Репніна та його активній участі в суспільнополітичному житті Малоросії того часу, вважають, щзо ніякого політичного підтексту у справі підготовки історії України, і ї̈ змісті не було, за задумом князя, підготовка праці такого спрямування мала на меті довести, щз малоросійська шляхта мала такі ж права на дворянство, а звідси і на чини, як і великоросійське дворянство. Акцентовано увагу на позииії, що М.Г. Рєпнін не лише здійснив намір багатьох культурних діячів того часу, замовивши написання систематичної праџі з історії України, але згуртував їх навколо себе, створивши таким чином своєрідний літературно-просвітницький гурток, характер 
якого визначали, перш за все, ті події $i$ ті настрої, що відбувалися в культурногромадському житті краӥни і панували серед украйнського панства, часом він набував політичного спрямування. Доведено, щчо хоча літературно-просвітницький салон М.Г. Рєпніна й існував, але ніколи не мав політичного спрямування. А головною заслугою у справі підготовки украӥнської історії як М.Г. Рєпніна, так і Д.М. Бантиш-Каменського полягає в тому, щзо вони здійснили задум багатьох своїх попередників, звівши виклад історичного матеріалу від найдавніших часів до 60-х рp. XVIII cm. в певну систему комплексної історї Украӥни. А також цей проект показав, щчо М.Г. Рєпнін фактично дав свою відповідь на «історіографічний виклик» імперського Петербурга. Адже при всій своїй «вписаності» в загальноросійську схему історичних подій "Історія Малої Росії» показувала особливості українських земель, передусім Гетьманщини.

Ключові слова: М.Г. Рєпнін (Волконський), генерал-губернатор, Д.М. БантишКаменський, Лівобережна Україна, новітня украӥнська історіографія, Історія Украӥни.

\section{HISTORIOGRAPHICAL REFLECTIONS ON THE PARTICIPATION OF M.G. REPNIN (VOLKONSKY) IN THE WRITING OF THE «HISTORY OF SMALL RUSSIA» by D.M. BANTYSH-KAMENSKY}

The article analyzes the historiography of the important role of M.G. Repnin (Volkonsky) in the preparation, writing and publication of the first synthetic work "History of Little Russia» by D.M. Bantysh-Kamensky. It is established that researchers in the XIX - early XXI centuries considered the contribution of M.G. Repnin to the preparation and writing of the history of Ukraine from various scientific positions. D.I. Doroshenko considered writing the history of Ukraine as a political matter. It is shown that, at the present stage, Ukrainian scientists, paying tribute to M.G. Repnin and his active participation in the socio-political life of Little Russia at the time, believe that there was no political implication in the preparation of Ukrainian history, and its content was not, according to the prince, the preparation of such work aimed to prove that the Little Russian nobility had the same rights to the nobility, and hence to the ranks, as the Great Russian nobility. Attention is drawn to the position that M.G. Repnin not only carried out the intention of many cultural figures of the time, ordering the writing of systematic work on the history of Ukraine, but united them around him, thus creating a peculiar literary and educational circle, the character of which was defined, first of all. everything, those events and those moods that took place in the cultural and social life of the country and dominated among the Ukrainian parish, at times it became political. It is proved that, although the literary and educational salon of M.G. Repnin existed, but never had a political orientation. And the main credit for the preparation of Ukrainian history for both M.G. Repnin and D.M. BantyshKamensky is that they carried out the design of many of their predecessors, reducing the presentation of historical material from the ancient times to the 1860s. into a certain system of complex history of Ukraine. And also this project showed that Repnin actually responded to the "historiographical challenge» of imperial Petersburg. After all, with all its «inscription» in the all-Russian scheme of historical events, "History of Little Russia» showed the peculiarities of Ukrainian lands, especially the Hetmanate.

Key words: M.G. Repnin (Volkonsky), Governor-General, D.M. Bantysh-Kamensky, Left Bank Ukraine, the latest Ukrainian historiography, History of Ukraine.

Вивчення історіографії, яка змальовує досвід діяльності окремих державних діячів, які зуміли не лише обійняти високу посаду, але й позитивно проявити себе в різних сферах суспільно-політичного, культурного та освітнього життя, при цьому вдало забезпечили поєднання загальнодержавних імперських інтересів 3 місцевими, регіональними є одним з перспективних напрямків. Показовою у цьому плані є політична кар'єра М.Г. Рєпніна-Волконського, піком якої став період, коли він перебував на посаді військового губернатора Лівобережної України (1816-1834). 
Враховуючи сучасні тенденції щодо збереження історичної пам’яті, яка є однією 3 підвалин національної ідентичності українців, важливим $\epsilon$ аналіз вагомої ролі М.Г. Рєпніна у підготовці, написанні та оприлюднені першої синтетичної праці «История Малой Росии» Д.М. Бантиш-Каменським. Крім того, актуальність та доцільність всебічного дослідження теми обумовлюється такими мотивами: відсутністю праць, в яких застосовувався комплексний підхід до вивчення історіографічного аспекту щодо ролі М.Г. Рєпніна в написанні першої синтетичної праці з української історії.

Новизна теми полягає в тому, що незважаючи на значну кількість публікацій оприлюднених, як на сторінках фахових видань, так і в пресі, тема потребує додаткового вивчення.

Значною справою, яка проводилася 3 ініціативи М.Г. Рєпніна було написання «История Малой России» Д.М. Бантиш-Каменским, який в молоді роки служив у князя чиновником 3 особливих доручень. Свою позицію щодо цього питання висловив I.Ф. Павловський, який писав, що головною заслугою у справі підготовки української історії як М.Г. Рєпніна, так іiі автора полягає в тому, що вони здійснили задум багатьох своїх попередників-істориків, звівши виклад історичного матеріалу від давніх часів до 60х років XVIII ст. в певну систему цілісної історії України [8, с. 182].

Надалі в історіографії дослідники розглядали справу написання історії України, передусім, як політичну. Так, Д.І. Дорошенко переконаний, що праця Д.М. БантишКаменського мала на меті не лише «пригадати часи гетьманів», себто, - дати образ української історії», але й - піддержати українську історичну традицію, домагання українського автономізму на правно-історичний грунт. 3 цього погляду, - наголошує він, «Исторія» Бантиша, при всій ії формальній льояльности щодо особи російського царя, мала свій політичний змисл і робила своє діло» [3, с. 108].

Сукупність історіографічних джерел щодо постаті М.Г. Рєпніна, які були опубліковані в радянський період у теоретичному та методологічному плані $\epsilon$ упередженими та застарілими, оскільки хибують на виключно класовий підхід. Крім того, зважаючи на приналежність М.Г. Рєпніна як до вищого чиновницького рангу Російської імперії, так і стану, радянські вчені спеціальної уваги цьому аспекту не приділяли [1; 7; 9].

На сучасному етапі українські дослідники трактують цей важливий аспект з різних наукових позицій. В.С. Шандра високо оцінюючи персоналій М.Г. Рєпніна та його активну участь в громадському та політичному житті Малоросії того часу, між тим зазначає, що ніякого політичного підтексту у справі підготовки історії України, і іiі змісті не було, за задумом князя, підготовка праці такого штибу мала на меті довести, що малоросійська шляхта претендує на такі ж права на дворянство, а звідси і на чини, як i великоросійське дворянство [10, с.117].

Натомість С.П. Дремлюга вважає, що задум підготовки й публікації першої аналітичної праці з історії України належить М.Г. Рєпніну, який не лише здійснив намір багатьох культурних діячів того часу, замовивши іï написання, але згуртував їх навколо себе, створивши таким чином, своєрідний літературно-просвітницький гурток, характер якого визначали, перш за все, ті події і ті настрої, що відбувалися в культурногромадському житті країни і панували серед українського панства, часом він набував політичного спрямування [4, с. 394].

Особливу думку щодо внеску М.Г. Рєпніна у цей проект подає дослідник П.М. Кралюк, який хоча й називає «Історію Малої Росії» офіційним виданням, але, як стверджує далі, це лише одна сторона медалі. $€$ й інша. Рєпнін фактично дав свою відповідь на «історіографічний виклик» імперського Петербурга. Адже при всій своій «вписаності» в загальноросійську схему історичних подій «Історія Малої Росії» показувала особливості українських земель, передусім Гетьманщини» [6, с. 20].

Мета статті - проаналізувати комплекс літератури та показати внесок генералгубернатора Лівобережної України (1816-1834) М.Г. Рєпніна в підготовку, написання та 
оприлюднення першої синтетичної праці «Истории Малой Росии» Д.М. БантишКаменського.

Один 3 перших хто звернув увагу на співпрацю М.Г. Рєпніна 3 місцевою інтелігенцією був етнограф та архівіст В.П. Горленко у розвідці «Из исторіи южнорусскаго общества начала XIX въка (письма В.И. Чарныша, А.И. Чепы, В.Г. Полетики и замътки къ нимъ) Съ портретом В.Г. Полетики» (1893). Дослідник переконаний, що дякуючи князю Д.М. Бантиш-Каменський знайомиться 3 відомим на той час збирачем старожитностей, знавцем до української історії Андрієм Чепою. Останній був уродженцем полтавської губернії, і збиранням історичних матеріалів та вивченням минулого займався 3 молодих років, коли ще служив у канцелярії правителя Малоросії П.А. Румянцева в 1779 р. [2, с. 42]. В.П. Горленко стверджує, що князь підтримував стосунки з всіма, хто на той час цікавився місцевою історією. Зокрема, дружив 3 Яковом Марковичем, Рігельманом, Берлінським, під кінець життя з Г. Полетикою [2, с. 43].

І.Ф. Павловський також описав плідну співпрацю М.Г. Рєпніна 3 Д.М. БантишКаменським. Зокрема у розвідці «К истории Малороссии во время генерал-губернаторства кн. Н.Г. Репнина: (Очерки, материалы, переписка по архивным данным)» (1905) дослідник зазначає, що Д. Бантиш-Каменському був відкритий для дослідження і особистий архів М.Г. Рєпніна, який знаходився в родинному маєтку його дружини Варвари Олексіївни Розумовської в Яготині. Проте, невідомо з яких причин у списку джерел своєї праці Д.М. Бантиш-Каменський яготинський архів М.Г. Рєпніна не згадує. Звичайно, він був знайомий і з М.Г. Рєпніним, і добре знав про любов князя до історії ввіреного йому краю. Тому останній знаючи, про давні вподобання А. Чепи до старожитностей, і в 1817 p. особисто звернувся до нього з листом в якому рекомендує Д. Бантиш-Каменського як талановитого дослідника української історії, і просить допомогти 3 «подлинными документами, могущими служить къ обагощенію ввъренного управленію моему края» [8, с. 9]. Крім того, стверджує дослідник, ще у 1819 р. князь М.Г. Рєпнін особисто звертався до чернігівського губернського прокурора - посприяти Д.М. Бантиш-Каменському в доступі у зібранні матеріалів 3 архіву міста. Тому завдяки клопотанню прокурора досліднику були видані 3 архіву 66 справ, які в основному відносилися до першої половини XVIII ст., а невелика частина до другої половини XVII ст. [8, с. 10].

Спеціальну розвідку з питання співпраці М.Г. Рєпніна з Д.М. Бантиш-Каменським було підготовлено Д.І. Дорошенком під назвою «Князь М. Рєпнін і Д. БантишКаменський: (Сторінка українського громадського життя першої четвертини XIX ст.)» (1929). За інформацією Д.І. Дорошенка: восени 1816 р. новопризначений генералгубернатор Малоросії (до цього регіону на той час входила Полтавська і Чернігівська губернії) М.Г. Рєпнін, збираючись їхати на місце своєї служби, вмовляє 28 річного дипломата Д. Бантиш-Каменського, який дістав призначення на посаду аташе при російській дипломатичній місії в Неаполь, поїхати разом із ним до Полтави. Він обіцяє йому посаду урядовця з особливих доручень при губернаторі, далі Д. Бантиш-Каменський навіть виконував деякий час обов'язки правителя канцелярії. Але основною місією М. Г. Рєпнін визначає для Д.М. Бантиш-Каменського написання систематичної історії України. Князь М.Г. Рєпнін обіцяє йому всіляку допомогу в цій справі, а головне для історика - відкрити доступ до місцевих архівів. Д.М. Бантиш-Каменський приймає запропоновану йому пропозицію. Загалом він пробув у Полтаві з 1810 по 1822 рік, й за цей час дійсно написав і видав свою «Історію Малої Росії», котра, як справедливо зазначає професор Д.І. Дорошенко поруч пізнішої «Исторіи Малороссіи» М. Маркевича, залишалася аж до початку XX ст. одиноким систематичним курсом української історії [3, c. 90].

Як далі стверджує Д.І. Дорошенко: «запрошення Д.М. Бантиш-Каменського для ролі творця української історії був невипадковий. М.Г. Рєпнін був добре обізнаний про дослідницький хист Д. Бантиш-Каменського, його знання в галузі історії, вмінні працювати з архівними документами. До того ж Д. Бантиш-Каменський знав добре мови 
та мав літературний хист, що на той час було великою рідкістю. А останній погодився, оскільки дуже поважав князя та його наміри, і вважав його за «справжнього героя, любителя доброчинності» [3, с. 20].

Дослідник С.П. Дремлюга у своєму дослідженні робить припущення, що ідея та ініціатива написання названої праці належала не М.Г. Рєпніну, а російському дипломату А.К. Розумовському, одному з братів Розумовських, котрий міг познайомити М.Г. Рєпніна у Відні з Д.М. Бантиш-Каменським [4, с. 386-397].

Цей аспект був проаналізований і сучасними історіографами В.П. Коцуром та А.П. Коцуром. Вони підтримують своїх попередників у тезі про те, що перебування в колі дворянської інтелігенції, яка гуртувалася навколо М.Г. Рєпніна, позитивно позначилося на заняттях Д.М. Бантиш-Каменського, тому знаючи про його хист, князь порадив йому написати синтезовану історію України і допомагав йому у цій роботі [5, с. 174].

Далі Д.І. Дорошенко вказує, М.Г. Рєпнін перш за все посприяв, щоби молодому досліднику був забезпечений доступ до архівних документів. Найціннішим з усіх таких архівів на лівобережній Україні в ті часи був архів при губернському правлінні в Чернігові. Тут переховувалися від 1786 р. останки архіву Малоросійської Колегії й Генеральної Військової Канцелярії, що збереглися після страшної глухівської пожежі 1784 р. Крім цього, тут переховувався архів чернігівської полкової канцелярії і гродського суду. Документи видано було під розписку Д. Бантиш-Каменського й самого М.Г. Рєпніна, який під час написання книги надавав поради досліднику. За свідченням Д. І. Дорошенка, вже в листопаді 1822 р. всі «діла» були повернуті до чернігівського архіву [3, с. 104].

Щоби пошвидше зреалізувати цей українофільський проект, у 1816 р. князь М.Г. Рєпнін вперше відвідав Чернігів з метою зустрітися з директором гімназії, відомим дослідником української старовини, М. Марковим. Краєзнавець передав йому свою друковану працю «О городахъ и селеніяхъ Черниговской губерній, упоминаемыхъ в літописи Нестора» $\mathrm{i}$ рукопис «О достопамятностяхъ Чернигова», який пізніше був видрукований 1847 році в московських «Чтеніях». Цей рукопис князь М.Г. Рєпнін повернув М. Маркову при листі з 30 листопада 1818 р., де дякує авторові «за одолженіе сихъ свъдъній, изъ коихъ многое извлечено для исторіи о Малороссіи, съ означеніемъ Вашего имени» [3, с. 105].

Як вказує І.Ф. Павловський, завдяки зв'язкам i рекомендації М.Г. Рєпніна, Д. Бантиш-Каменському пощастило познайомитися з багатьма особами, які надавали йому матеріали та корисні поради, і про яких він вказує у своїм списку джерел. За словами I.Ф. Павловського, участь князя в творенні «Історії Малоросії» Д. Бантиш-Каменського обмежувалась не тільки ініціативою й допомогою у зібранні документів, його перу належить розділ про битву під Берестечком [8, с. 5; 9]. Про це пише й Д.І. Дорошенко, зазначаючи, що сам Д. Бантиш-Каменський у передмові до першого видання вказує: «Трудъ сей предпринялъ я по порученію Г. Малороссійскаго Военнаго Губернатора, управляющаго и гражданской частью въ губерніяхъ Черниговской и Полтавской, кн. Н.Г. Репнина. Сему почтенному начальнику моему, обязанъ я многими источниками и непосредственним участіемъ в первой книгъ Описаніе Берестечскаго сраженія єсть произведеніе пера его» [3, с. 105].

Як далі стверджує фахівець з цього питання Д.I. Дорошенко, який порівняв вступ про Берестецьку битву з текстом цілої Д. Бантиш-Каменського праці, «помітної різниці щодо стилю між цим вступом і рештою викладу - нема, але сам по собі опис дуже ясний, хоч і стислий. Він увесь заснований на польській реляції про битву, збереженій у Московськім Коллежськім Архіві. У другому виданні своєї «Исторіи» Бантиш, видко, склав опис Берестецької битви вже сам: виклад поширений і опертий майже виключно на Пасторіеві; про польську реляцію вже не згадується» [3, с. 106].

За інформацією І.Ф. Павловського, наприкінці 1830 р. Д. Бантиш-Каменський підготував друге видання своєї праці та звернувся до М.Г. Рєпніна в листі з проханням 
допомогти матеріально у іiі виданні, та «в открытіи подписки на означенну исторію». Виконуючи його прохання М.Г. Рєпнін розіслав листи губернаторам чернігівському й полтавському, пропонуючи їм посприяти у поширені передплати на «Історію Малої Росії». У листі він зазначає: «многіе дворяне управляемой вами губерніи, без сомнънія пожелаютъ имъть у себя полезную и любопытную для каждого изъ здъшнихъ жителей книгу» $[8$, с. 11]. Князь також в приватному листі листі замовив у Д. Бантиш-Каменського два примірники книги на 50 рублів [8, с. 12].

Підводячи підсумки, щодо висвітлення в історіографії цього успішного українофільського проекту князя М.Г. Рєпніна 3 Д.М. Бантиш-Каменським сучасний вітчизняний історик О.В. Ясь наголошує, що Д. Бантиш-Каменський в останні роки життя з теплотою згадував ті роки, коли він служив у князя М. Рєпніна-Волконського та їхню плідну співпрацю над першою синтетичною історією України [11, с. 187].

Таким чином, в історіографії XIX - початку XXI ст. дослідники розглядали участь у проекті генерал-губернатора Лівобережної України М.Г. Рєпніна (Волконського) щодо підготовки та написання синтетичної історії України з різних наукових позицій. Перші дослідники старожитностей вважали, що завдяки сприянню генерал-губернатора М.Г. Рєпніна, Д.І. Бантиш-Каменському вдалося написати комплексну історію України, звівши виклад історичного матеріалу від давніх часів до 60-х років XVIII ст. Д.І. Дорошенко дотримувався позиції щодо політичного підтексту у меті іiі написання. Сучасний дослідник С.П. Дремлюга акцентує увагу на тому, що М.Г. Рєпнін не лише здійснив намір багатьох культурних діячів того часу, замовивши написання систематичної праці з історії України, але згуртував їх навколо себе, створивши таким чином своєрідний літературно-просвітницький гурток, характер якого визначали, перш за все, ті події і ті настрої, що відбувалися в культурно-громадському житті країни і панували серед українського панства, часом він набував політичного спрямування. В.С. Шандра переконана, що ця справа показала лише прагнення князя історично довести право малоросійської шляхти на спадкове дворянство та чини в урядових установах Російської імперії. Домінуючою для нас є оцінка П.М. Кралюка про те, що М.Г. Рєпнін та іï автор у цьому проекті запропонували не лише концепцію, яка обгрунтувала вірнопідданість української шляхти, а з тим і іï право на великоросійські чини, а, насамперед, ця справа показала особливість та окремішність українських земель, передусім Гетьманщини.

\section{ДЖЕРЕЛА ТА ЛІТЕРАТУРА}

1. Бутич М. І. До історії створення та діяльності генерал-губернаторств і військових губернаторств на Україні (кінець 18 - поч. 20 ст.) // Історичні дослідження. Київ, 1985. Вип.11. С. 45-50.

2. Горленко В. Из исторіи южно-русскаго общества начала XIX въка (письма В.И. Чарныша, А.И. Чепы, В.Г. Полетики и замътки къ нимъ) Съ портретом В.Г. Полетики // Кіевская старина. 1893. Т. 40. С. 41-76.

3. Дорошенко Д. Князь М. Рєпнін і Д. Бантиш-Каменський: (Сторінка українського громадського життя першої четвертини XIX ст.) // Пр. Укр. високого пед. Ін-ту ім. М. Драгоманова. Прага, 1929. Т. 1. С. 90-108.

4. Дремлюга С. П. 3 історії суспільно-політичної думки України першої половини XIX ст. Гурток князя М. Г. Рєпніна-Волконського // Дніпропетровськ. іст.-археогр. зб. Дніпропетровськ. 1997. Вип. І. На пошану професора М. П. Ковальського. С. 386-397.

5. Історіографія історії України: Курс лекцій / Коцур В.П., Коцур А.П. Чернівці: Золоті литаври, $1999.520 \mathrm{c.}$

6. Кралюк П. Покровитель українських автономістів // День. 2019. №161-162.

7. Мироненко С.В. Самодержавие и реформы. Политическая борьба в России в начале XIX в. Москва: Наука. 1989. 240 с.

8. Павловский И.Ф. К истории Малороссии генерал-губернаторства во время генерал-губернаторства кн. Н. Г. Репнина: (Очерки, материалы, переписка по архивным 
данным) // Труды Полтавской Ученой Архивной Комиссии. Полтава, 1905. Вып. 1. С.49154.

9. Предтеченский А.В. Очерки общественно-политической истории России в первой четверти XIX века. Москва, Ленинград: АН СССР. 1957. 456 с.

10. Шандра В.С. Малоросійське генерал-губернаторство, 1802-1856: функції, структура, архів. Київ, 2001. 356 с.

11. Ясь О.В. «Свій» серед «чужих», «чужий» серед «своїх». «История Малой России» Д. Бантиша-Каменського у світлі українсько-російського культурного перехрестя (до 220-річчя Дмитра Бантиша-Каменського) // Український історичний журнал. 2009. № 2. С.160-194.

\section{REFERENCES}

1. Butych, M.I. (1985). Do istoriyi stvorennya ta diyal nosti general- gubernatorstv i vijs `kovyx gubernatorstv na Ukrayini (kinecz 18 - poch. 20 st.) [The history of the creation and activity of governorates-general and military governorates in Ukraine (the end of the 18th - the beginning of the 20th centuries)]. Istory chni doslidzhennya-Historical Studies. Kyiv, vol. 11, pp. 45-50 [in Ukrainian].

2. Gorlenko, V. (1893). Iz istorii yuzhno-russkago obshchestva nachala XIX veka (pis'ma V.I. Charnysha, A.I. Chepy, V.G. Poletiki i zametki k nim) S portretom V.G. Poletiki. [From the history of the South Russian society of the beginning of the 19th century (letters of V.I. Charnysh, A.I. Chepa, V.G. Poetics and shorts to him) With a portrait of V.G. Flights]. Kievskaya starina -The Old Kiev. T. 40. P. 41-76 [in Russian].

3. Doroshenko, D. (1929). Kniaz M. Riepnin i D. Bantysh-Kamenskyi: (Storinka ukrainskoho hromadskoho zhyttia pershoi chetvertyny XIX st.) [Prince M. Repnin and D. Bantysh-Kamensky: (Page of the Ukrainian public life of the first quarter of the 19th century)]. Pr. Ukr. vysokoho ped. In-tu im. M. Drahomanova-Pr. Ukr. high ped. In them. M. Drahomanov. Praha, T. 1. pp. $90-108$ [in Ukrainian].

4. Dremlyuga, S.P. (1997). Z istoriyi suspil no-politychnoyi dumky Ukrayiny pershoyi polovyny XIX st. Gurtok knyazya M.G. Ryepnina-Volkons`kogo [From the history of sociopolitical thought of Ukraine in the first half of the nineteenth century. Circle of Prince M.G. Repnin-Volkonsky]. Dnipropetrovs`k. ist.-arxeogr. zb. - Dnepropetrovsk. archeogr. Sat. Dnipropetrovsk. Dnipropetrovsk, vol. 1, Na poshanu profesora M.P. Koval`s`kogo, pp. 386-397 [in Ukrainian].

5. Istoriografiya istoriyi Ukrayiny: Kurs lekcij (1999). [History of Ukraine: Course of lectures]. Chernivtsi: Zoloti ly`tavry [in Ukrainian].

6. Kralyuk, P. (2019). Pokrovytel ukrayins `kyx avtonomistiv [Patron of Ukrainian Autonomists]. Den - Day, no 161, pp. 161-162 [in Ukrainian].

7. Mironenko, S.V. (1989). Samoderzhavie i reformy. Politicheskaja bor'ba v Rossii $v$ nachale XIX v. [Autocracy and reform. Political struggle in Russia at the beginning of the XIX century]. Moscow: Nauka [in Russian].

8. .Pavlovskiy, I.F. (1905). K istorii Malorossii general-gubernatorstva vo vremya general-gubernatorstva kn. N. G. Repnina: (Ocherki, materialy, perepiska po arkhivnym dannym). [To the history of Little Russia, the Governor-General during the Governor-General of Prince. N.G. Repnina: (Essays, materials, correspondence on archival data)]. Trudy Poltavskoy Uchenoy Arkhivnoy Komissii - Proceedings of the Poltava Academic Archival Commission. Poltava, Vol. 1, 49-154 [in Russian].

9. Predtechenskij, A.V. (1957). Ocherki obshhestvenno-politicheskoj istorii Rossii v pervoj chetverti XIX veka [Essays on the socio-political history of Russia in the first quarter of the 19th century]. Moscow, Leningrad: AN SSSR [in Russian].

10. Shandra, V.S. (2001). Malorosijs ke general-gubernatorstvo, 1802-1856: funkciyi, struktura, arxiv [The Little Russian Governor-General, 1802-1856: Functions, Structure, Archives]. Kyiv [in Ukrainian]. 
11. Yas, O.V. (2009). «Svii» sered «chuzhykh», «chuzhyi» sered «svoikh». «Ystoryia Maloi Rossyy» D. Bantysha-Kamenskoho u svitli ukrainsko-rosiiskoho kulturnoho perekhrestia (do 220-richchia Dmytra Bantysha-Kamenskoho). [«Yours» among «strangers», «strangers» among «your own». «History of the Little Russian» by D. Bantysh-Kamensky in the light of the Ukrainian-Russian cultural crossroads (220-year-old Dmitry Bantysh-Kamensky)]. Ukrainskyi istorychnyi zhurnal - Ukrainian Historical Journal, 2, 160-194 [in Ukrainian].

Одержано 18.04.2019.

УДК 94:[001:37-051(477)«1985/1991»

Потапенко Руслана,

викладач кафедри історії та культури України

rusyapotapenko007@gmail.com https://orcid.org/0000-0002-3521-9462

Державний вищий навчальний заклад «Переяслав-Хмельницький державний педагогічний університет імені Григорія Сковороди», вул. Сухомлинського, 30, м. Переяслав-Хмельницький, Київська обл., Україна, 08401

\section{DOI https://doi.org/10.31470/2415-3567- 2019-46-225-232}

\section{Potapenko Ruslana,}

Lecturer of the Department of History and Culture of Ukraine rusyapotapenko007@gmail.com https://orcid.org/0000-0002-3521-9462

Pereiaslav-Khmelnytskyi Hryhorii Skovoroda State Pedagogical University, 30, Sukhomlynsky Str., Pereiaslav-Khmelnytskyi, Kyiv region, Ukraine, 08401

\section{НАУКОВО-ОСВІТНЯ ІНТЕЛІГЕНЦІЯ В ПРОЦЕСАХ ТРАНСФОРМАЦЇ̈ УКРАЇНОЗНАВЧИХ СТУДІЙ В ПЕРІОД СУСПІЛЬНО-ПОЛІТИЧНИХ ПЕРЕТВОРЕНЬ (1985-1991)}

У статті простежено як радянська влада боролася з проявами національної свідомості в Украӥні. Висвітлено актуальні питання щцодо украӥнознавчого аспекту дослідження історії України в добу Перебудови (1985-1991 рр.). Адже, в формуванні національної самосвідомості українського народу важливе значення посідало відновлення історичної пам'яті, осмислення або переосмислення історичної місії в контексті загальночивілізаційного поступу. Важливу роль в даних процесах відігравали вчителіпатріоти, науковиі, які підтримували ідею незалежної $і$ суверенної Украӥни. Формуючи украӥнську націю вони звертали свої погляди на украӥнознавство, а уроки з даної тематики сприяли усвідомленню приналежності до певного народу, який має свою історію, культуру, духовну спадщину.

На долю українського народу випали важкі випробування, які були викликані іï колоніальним поневоленням, особливо в частині національної самобутності. Для досягнення результату використовувалися всі методи, засоби, починаючи від демагогії, утисків, фальсифікацій, заборон і закінчуючи нищенням, репресіями національної еліти, інтелігениії, щзо становила ядро нації.

У часи Перебудови виникла ідея стосовно створення першого в Україні науковоосвітнього центру, який би займався виріменням практичних завдань, а саме - творив би національну освіту, науку, виховання. Так за інічіативи декана філологічного факультету Київького державного університету імені Тараса Шевченка П. Кононенка в 1988 р. було створено Центр українознавства. 